\title{
Corrective Feedback in the Saudi EFL Writing Context: A New Perspective
}

\author{
Sami Ali Nasr Al-wossabi \\ English Department, Faculty of Arts and Humanities, Jazan University, Jazan, Saudi Arabia
}

\begin{abstract}
Corrective feedback (CF) in writing classes has been a central issue in the field of SLA. Various SLA studies recommended that raising the awareness towards EFL students' perceptions and attitudes of CF practices might lead to more effective learning of writing skills and more successful teaching methods in the $\mathbf{L 2}$ classroom (Ellis, 2009; Ferris, 2007; Lee, 1997; Pawlak, 2014). The present paper proposes a new perspective towards the use of CF practices in writing classes at the Saudi EFL context. The study, therefore, aims at collecting necessary data on students' attitudes towards the proposed practices of CF and finding out whether such practices would be positively or negatively perceived by students. It also aims at finding out whether or not such practices are beneficial for students. The results showed approval on the use of the proposed practices of CF among the majority of participants. Participants were motivated and exhibited patent ability for selfcorrection.
\end{abstract}

Index Terms — error correction, corrective feedback, explicit correction, L2 writing

\section{INTRODUCTION}

Though it has been documented that EFL/ESL students did appreciate and value their teachers' attempt to correct their errors (Leki, 1991; Zhang, 1999), it has been widely observed by teachers and stakeholders that many EFL Saudi students found writing assignments boring and overwhelming. What could justify such a predicament is the fact that many EFL teachers mechanically and explicitly correct their students' errors while writing harsh comments that scattered all over their writing sheets. A question that poses itself here, is whether or not students will benefit from such overwhelming corrective feedback. Besides, approaching students' language performance in writing using one-way strict evaluation and systematically assigning marks may result in putting students at irremediable disadvantages. It may also drift them away from the learning processes that students are supposed to experience and internalize. That could be why some SLA researchers strongly argued that error correction followed by feedback had few positive effects on students' development of L2 grammar and writing accuracy (Kepner, 1991; Semke,1984; Sheppard, 1992; Truscott, 2007)

Despite the fact that CF is an immediate concern and a part of teachers' job in writing classes, EFL Saudi students continue to make mistakes regardless of how many times their errors have been dealt with by their teachers. The same phenomenon was noticed in ESL classes too (Semke, 1984; Sheppard,1992; Kepner,1991).

Teachers usually correct errors by writing the proper grammatical or lexical form on students' writing papers. Many students, on the other hand, are no longer interested in considering the comments or correction written on their assignments particularly if these assignments had already been allocated to low marks. This could also be one of the reasons that lies behind students' resistance against benefiting from the way their teachers approach their assignments. They might feel that there is no avail in taking a step further in enhancing their writing skills particularly if they repeatedly commit mistakes and are assigned low marks. Therefore, as suggested by Hyland (2003), written feedback that teachers provided on their students' writing should be "more than marks on a page" (p. 184).

Correcting every single error in students' compositions may not be practical or beneficial after all. It may widen the gap between teachers' correction and the way this correction is perceived by students and the extent to which this CF is positive or negative. According to Green (1993) and Garrett and Shortall (2002), L2 learners are unable to discriminate between what helps or hinders progress towards language learning. Such discrepancy between teachers and students is believed to generate unfavorable attitudes on the parts of students while triggering pressure, demotivation and frustration. (Garrett \& Shortall, 2002; McDonald \& Salomone, 2012;Morris \& Tarone, 2003; Noels, 2001; Peacock, 2001; Tse, 2000; Yang, 2010).

The researcher's stand is that CF in writing classes could either be useful or damaging to students' developmental processes in writing in a foreign language. Hence, the study suggests a less threatening mechanism for error correction and feedback in writing classes as to enable students better acquire necessary skills for writing in a more productive learning environment. Productivity is likely to be seen in students when they are encouraged to take responsibility of their own learning. To put it differently, students can always be prepared to be autonomous learners even it is the responsibility of the teachers to guide and correct their drawbacks.

The study advocates a different approach on how students can positively perceive and appraise CF through transferring some of the teachers' responsibility of correcting errors to be in the hands of their own students. It suggests 
that instead of correcting and commenting on students' errors and mistakes in writing, those errors can only be pointed out by teachers. Students, then, can undertake the process of correction themselves and then returned their assignments back to their teachers to be discussed, guided or partially corrected.

The following literature review will discuss the issue of corrective feedback (CF) from an SLA perspective. It will look at the differences in teachers' and students' perceived roles of CF in the L2 classroom, the impact of CF on L2 learning and the differing stances of $\mathrm{CF}$.

\section{LITERATURE REVIEW}

\section{A. Teachers' and Students' Perceived Roles of CF}

Numerous researchers (McCargar, 1993; Miley \& Gonsalves, 2003; Noels, 2001; Peacock, 2001; Schulz, 2001) noted that there is often a perceptual mismatch between L2 students and their teachers of what is facilitative and effective in terms of language teaching and learning. More often, problems in L2 acquisition may arise as a result of such differing views on the part of the students as well as the teachers (Green, 1993; Schulz, 2001).

Further, Noels et al. (1999) found that when students view their teachers as controlling and not supporting their autonomy are more likely to be demotivated, more anxious and less interested in continuing studying the language. Other researchers found that when $\mathrm{CF}$ is not matching with the students' perceptions of what is effective produced different levels of negative feelings in students (Garrett \& Shortall, 2002; Green, 1993; Morris \& Tarone, 2003). Hyland (2000) in her work of ESL writers and their perceptions of teacher feedback, suggested that teachers should encourage their students to accept greater responsibility over their written work.

Lasagabaster and Sierra (2005) investigated the role of explicit CF in facilitating language learning and the perceived role of $\mathrm{CF}$ by students. The researchers concluded that students failed to recognize a significant number of their teachers' corrections. They also found that both teachers and students agreed that CF was more effective when given ample time and sufficient explanations. Silver and Lee (2007) found that students respond more effectively to feedback in the form of advice than when it stems from criticism or praise. According to Silver and Lee (2007), "advice effectively communicates to students the defining role of the teacher as a mentor or a facilitator rather than a critic or an evaluator" (p. 40). Straub's (1997) study also found that students responded positively to feedback that offered help or direction.

As discussed above, many SLA research that investigated the students and teachers' perceived role of written feedback suggested that a less controlling role of teachers to $\mathrm{CF}$ and some ownership for students over their written work would have a more facilitative role towards better language learning. On the other end of the continuum, many SLA researchers claimed that CF in both written and spoken language is valued and seen as a necessary technique by many L2 students who generally rated CF as a better tool than other types such as peer correction (Green, 1993; McCargar, 1993 Peacock, 2001; Schulz, 2001).

Ancker (2000) compared teachers' and students' perceptions on error correction. Although, teachers did not use redundant explicit feedback, encourage peer editing and self-correction, students expressed their preference to only teachers' explicit feedback, modeling and repetition. Hyland and Hyland (2001) examined students' and teachers' perceptions of different forms of written feedback (i.e., praise, criticism, and suggestion). They found that there is significant contradiction in perceptions between students and teachers and obvious variation that existed between students and students themselves.

Overall, it seems that despite the differing views on how teachers vs students perceive $\mathrm{CF}$, the conclusion to be drawn here is that CF was valued by all students.

\section{B. The Impact of CF on L2 Learning}

Corrective feedback has been one of the most debated issues in SLA. Many SLA studies have pinpointed its necessity and how it can be best exploited in instructed L2 classrooms. ( Bitchener, Young, \& Cameron, 2005; Ellis, 2009; Ferris, 2011; Lyster, Lightbown, \& Spada, 1999; Mantello, 1997; Pica, 1994; Schultz, 2001; Truscott, 1996; Truscott, 1999a; Truscott, 1999b). Although, CF is viewed as necessary to better acquisition of L2, older SLA studies clearly showed that there is a positive relation between teachers' amount of CF and lower gains on the part of students (McCargar,1993; DeKeyser,1993, Truscott, 1996, 1999a).

In contrast, others claimed that CF is an effective tool for the L2 classroom suggesting that teachers need to consider students' natural order of acquisition as well as their level of readiness to acquire particular structures (Lightbown \& Spada, 1999b; Lyster et al., 1999).

Some studies of second and foreign language in academic contexts revealed students' strong tendency for formfocused feedback on all their errors (Ellis et al., 2001; Hyland, 2003; Leki, 1991). Hedgcock and Lefkowitz (1994) proposed that such preference is due to two major factors: (a) learners' view of language as a form of practice (b) Teachers' priority given to form. Such studies also revealed that L2 students were very keen about using English correctly and traditionally while expecting their teachers to automatically respond to their written errors (Ferris, 2007; Lasagabaster \& Sierra, 2005 ). Others claimed that due to students' past experience in language classrooms they expected attention to be given to grammar correction in the classroom (Ferris,2011; Lee, 2004; Porte, 1997; Truscott, 
1999b). Noels et al. (1999) suggested that students tend to view CF as productive not as judgmental while rating explicit correction as the most favorable type of feedback

The issue of $\mathrm{CF}$ seems to generate lots of controversy taking into account the conflicting results and different views of the practicality of CF in the ESL/EFL contexts. Those in favor of error correction reflect merely students' agreement to the importance of it but not their actual preferences or needs. Moreover, many studies confirmed that teachers' feedback failed to improve students' accuracy in writing. And that despite the emphasis placed on error correction by both teachers and students, students still make the same mistakes even if they are corrected several times on different occasions (Kepner, 1991; Loewen, et., al; 2009; Semke,1984; Sheppard,1992). This does not necessarily mean to altogether abandon CF in writing classes as ineffective and harmful to students (Truscott (1996). Rather it would be wiser to consider either changing teachers' practices or meeting students' preferences or both (Tarone \& Yule, 1985; Schulz, 2001).

More recent SLA studies, focusing on foreign language pedagogy, admitted the facilitative role of CF in relation to how language is learnt in particular from the perspective of interactionists (e.g. task-based instruction-focus on form/meaning) and skill-learning approaches. Harmer (2007b) considered feedback globally as, "a crucial part of the learning process (p. 127). Lantolf and Thorne (2007) pointed out that CF as it enhances noticing of forms, leads to output modification and triggers self-regulation. In the same vein, other researchers recommended the use of specific types of CF and under certain conditions to integrate meaning and form (Savignon, 2005; Littlewood, 2011; Ellis, 2005b; Noris, 2009; Robinson, 2011; Lyster, 2011).

\section{SLA Approaches to Corrective Feedback}

Unfortunately, many teachers view error correction as globally accepted and unquestionable. In the EFL context, students may indeed contribute towards more effective and pedagogical CF if consulted. Hence, there is a great need to delve into the issue of CF and find specific corrective techniques and practices to effectively deal with students' errors (Pawlak, 2014). Bridging the gap in perceptions of the type of feedback to be used and how frequently to be provided is a major concern in the SLA literature.

Many studies, however, claimed that implicit feedback coupled with verbal conferencing can help students in writing classes more than any other type of feedback. This is because students can pay more attention to errors, be guided about the rules and given an opportunity to self-correct their errors (Ferris, 2011; Lee, 2004; Leki, 1991).

Hyland and Hyland's (2001) study on teachers' feedback on writing acclaimed the students 'needs and preferences and called for the need to change practices of CF accordingly. Noels (2001) claimed that by acknowledging students' preferences and needs, they will ultimately view $\mathrm{CF}$ as a positive technique and that could minimize any negative or affective results that may originate from CF. Hyland (2003) advised teachers to undertake corrective feedback while illustrating to students that they are all participants in the process of error correction. Peacock (2001) asserted that teachers should incorporate different strategies of error correction in relation to the preferences of the students irrespective of their level of agreement with the teacher. He also recommended that such strategies should address the expectations of all or most students as it is unfeasible to adapt corrective feedback to all students' preferences and styles within the same class. Yates and Jenkel (2002) claimed that the teacher should presuppose the students' perceptions of $\mathrm{CF}$ when commenting on their writing. However, the researchers' views were basically addressing the students' linguistic input rather than their needs.

As for what type of errors should be treated first, Ferris (1999) distinguished between treatable errors and untreatable errors suggesting that not all errors are to be congruently treated the same. For instance, some types of errors can easily be noticed and corrected such as subject-verb agreement, article usage, noun pluralization and spelling, while errors resulted from word choice and idiomatic usage can be challenging (Ferris, 2007; Ferris \& Roberts, 2001; Lee, 1997). This view suggested that teachers can selectively correct errors rather than expansively. However, selective error treatment might not be appealing to many EFL teachers. This is because teachers are traditionally used to one way comprehensive error treatment and that many students themselves might not tolerate their teachers' abandonment of correcting particular errors (Hyland, \& Hyland, 2001). Therefore, as Hyland (2003) suggested that teachers should negotiate with their students the outcomes of $\mathrm{CF}$ techniques specifically set for the students.

In light of this comparison of the recommendations found in the literature with regard to $\mathrm{CF}$, it seems that they are not contradictory nor are they in total agreement. However, most recommendations differ only on the way they approach CF whether in the ESL or EFL educational settings. Yet, most researchers agree that CF is central to the second and foreign language pedagogy. This study shares the same views pertaining the necessity and the facilitative role of corrective feedback for L2 students with an aim at generating more productive and effective practices for error correction in the EFL classroom. Further, this study is also an attempt to bridge the gap between both teachers and students' perceptions of CF by engaging students in the process of correcting their errors and under the guidance of their teachers. The following is a detailed account of the procedures to be followed for this study.

\section{METHODOLOGY}

\section{A. Participants}


Sixty students were chosen randomly and were asked to reflect upon their views of the way their teacher correct their writing composition in writing class (2). They have had writing class (1) with the same instructor. Their language levels are between beginners and high intermediate.

\section{B. Design}

The questionnaire, by means of a five point likert-scale, was devised to examine Saudi EFL students' attitudes towards their teachers' new practices of corrective feedback suggested in this study. The questionnaire included twelve statements along with a space at the end for students to add any further comments. The questionnaire's statements were simple and direct in order to elicit practical values and informative views from students towards their teacher's new practices of corrective feedback. The respondents were asked to express either agreement or disagreement attitudes towards the item in question.

Each statement was given a numerical score to represent its degree of attitudinal approval. The items were carefully stated to avoid any unfairness or bias in favor of either sides of the likert scale. Students were previously informed that their identities would remain anonymous in order to confidently describe their stances. Further, the researcher conducted group conferences with the participants after the questionnaire was carried out. The aim was to reduce any leniency or preference on the part of the participants and to elicit more responses in case the questionnaire underrepresent other informative aspects of students' experiences.

\section{Procedure}

The questionnaire was carried out towards the end of the semester in writing class (2) The participants have had already one class in writing (writing class1). They had the same instructor in both writing classes (1) and (2). For the purpose of this study, the instructor was requested to alter his policy of corrective feedback used in previous writing classes. He was informed to consider and incorporate the following guidelines:

1 The instructor need to acknowledge his students' attitudes towards CF and discuss with them the goals for CF practices to be used (Ellis, 2009).

2 The instructor can only point out students' local / global errors preferably by underlining rather than circling.

3 Explicit correction can be used sparingly when there are instances of potentially difficult global errors that might affect the overall meaning of sentences. Therefore, the instructor should use a wide variety of feedback alternatives. Similar to what is suggested by Ellis (2009), the instructor can "start with a relatively implicit form of correction (e.g., simply indicating that there is an error) and, if the learner is unable to self-correct, to move to a more explicit form (e.g., a direct correction)" (P.13).

4 The instructor needs to train students to correct their own errors.

5 Students should have ample time in class for self-correction by examining, evaluating and correcting their errors to the best of their previous and existing knowledge of grammar, word choice and meaning. According to Ellis, (2009), "Teachers need to create space following the corrective move for learners to uptake the correction ... learners need the opportunity to attend to the corrections and revise their writing" (P.13).

6 At the same time, the instructor should be all set to answer and discuss students' queries and suggestions pertaining their errors inside the classroom.

7 The instructor may allow student themselves initiate negotiating their errors from time to time.

8 The instructor needs to appreciate students' progress and regularly make positive comments on their performance .

9 The instructor should adapt his practices of $\mathrm{CF}$ and ensure that such practices are not a source for anxiety among students (Ellis, 2009).

The above guidelines are meant to familiarize students with the proposed techniques of CF in this study that they are not used to and to examine the effectiveness of such techniques and their usability and practicality in the L2 classroom. Further, they are not to be imposed on teachers as mandatories. Rather, they are prepositions that are adaptive and debatable (Ellis, 2009).

Pertaining, the questionnaire, the participants were informed that they could ask questions whenever they found difficulty understanding the survey statements. The participants were encouraged to give thoughtful responses to the survey. They were also told to report on any other thoughts they might have via emails. The aim was to lessen the pressure that could result from being involved in such task and to eliminate any feelings on their part of judging their own teachers

Besides, to minimize the possibility of students asking others to help them correct their errors, students are allowed to work on their errors only inside the classroom while revising their composition with peers or/and their instructor.

\section{Discussion OF THE RESUlTs}

For the present study, higher means show the positive side of the likert scale and indicate more positive attitudes on the part of the students towards some or all of their teacher's new practices of CF on their writing composition. As stated above the new practices used for this study entail the involvement of the students in correcting and discussing their errors in writing. On the other hand, lower means show negative attitudes suggesting that students are not in favor of some or all of their teacher's new approach of error correction. 
As shown in table (1) items from 2 to 7 constitute substantial significance towards more positive attitudes of the teacher's new practices of EC as their means are (4.65 - 4.05 - 4.00- 4.33- 4.6 - 4.5) respectively.

Such agreement among participants does contribute significantly to the overall impression of learners with regard to most of their teachers' new practices of CF. This is evident considering the higher means of items 2 to 7 which lead to the conclusion that EFL Saudi students showed positive attitudes towards the use of the suggested new practices of $\mathrm{CF}$ proposed in the present study.

On the other hand, item 1 has a lower mean of 1.66 compared to other means on the likert scale. This mean as indicated above does constitute a substantial significance towards the negative side of the Likert scale. Item 1 is the only item that shows negative attitudes towards whether or not the new CF practices are suitable to all students. The majority of students disagree that such practices could be suitable to all students.

TABLE I

ITEMS SHOWING THE EXTENT TO WHICH SAUDI STUDENTS AGREE/DISAGREE WITH THEIR TEACHER'S NEW PRACTICES OF ERROR CORRECTION.

\begin{tabular}{|l|l|l|l|l|l|}
\hline & $\begin{array}{c}\text { Strongly } \\
\text { Disagree (1) }\end{array}$ & $\begin{array}{c}\text { Disagree } \\
\text { (2) }\end{array}$ & $\begin{array}{c}\text { Undecided } \\
\text { (3) }\end{array}$ & $\begin{array}{c}\text { Agree } \\
\text { (4) }\end{array}$ & $\begin{array}{c}\text { Strongly agree } \\
\text { (5) }\end{array}$ \\
\hline $\begin{array}{l}\text { 1. I think that my teacher's new way of error } \\
\text { correction is suitable for all students. }\end{array}$ & & & & & \\
\hline $\begin{array}{l}\text { 2. I feel more interested and motivated in correcting } \\
\text { my errors with the help of my teacher or } \\
\text { classmates. }\end{array}$ & & & & & \\
\hline $\begin{array}{l}\text { 3. I prefer my errors to only be pointed out by my } \\
\text { teacher }\end{array}$ & & & & & \\
\hline $\begin{array}{l}\text { 4. I like to be given a chance to correct my errors } \\
\text { that are pointed out by my teacher }\end{array}$ & & & & & \\
\hline $\begin{array}{l}\text { 5. Discussing my errors with my teacher help me } \\
\text { better understand my errors }\end{array}$ & & & & & \\
\hline $\begin{array}{l}\text { 6. Peer editing of writing compositions with my } \\
\text { classmates is useful }\end{array}$ & & & & & \\
\hline $\begin{array}{l}\text { 7. I feel disappointed when my composition is full } \\
\text { of corrections }\end{array}$ & & & & & \\
\hline
\end{tabular}

TABLE II

DESCRIPTIVE STATISTICS OF 5-POINT LIKERT-SCALE ITEMS FROM ITEM 1 TO ITEM 7: (N:60)

\begin{tabular}{|c|c|c|}
\hline Item & Mean & Standard deviation \\
\hline 1 & 1.6 & 0.66 \\
2 & 4.65 & 0.51 \\
3 & 4.05 & 0.69 \\
4 & 4.00 & 0.59 \\
5 & 4.33 & 0.48 \\
6 & 4.6 & 0.50 \\
7 & 4.5 & 0 \\
\hline
\end{tabular}

Upon group interviews with students to speculate more on their opinion on the suggested practices of CF, it was found that high achievers were coping very well with the new practices of CF. On the other hand, although, lower achievers like their teachers to proceed with the new practices of $\mathrm{CF}$, they sometimes felt that they are left behind as they are slower learners. Further, low achiever found it unfair to be given the same chance and time for correcting mistakes considering that high achievers are faster and more proficient in approaching errors of their writing. This could be why item 1 has lower means showing that most high/ low achievers generally do not think CF is suitable for all students considering their varying levels. Henceforth, it should be suggested that such practices need to be implemented gradually so all students can have sufficient time for revising and practicing the grammatical functions they were exposed to in their earlier and current grammar and writing classes.

Interviewing the instructor of the course, it was found that students were remarkably able to edit most of the errors pointed out by their teachers. This is concurrent with previous SLA studies where students were given opportunities to correct their errors on their own (Ferris \& Roberts, 2001; Lee, 2004; Yang, 2010). This ability was developed and enriched after several and regular attempts of students correcting their errors either on their own or with the help of their peers or/and their teachers. Such experiences are to be expected considering the fact that students already have the knowledge of basic grammatical forms and that they are applying these forms in their own writing. Thus, what is missing is merely practicing and trying out such linguistic and grammatical forms.

Thus, based on the students' attitudes and their performance on correcting their own errors, the implication to be withdrawn here is that Saudi students need to be engaged in the process of error correction while fully considering their varying levels and needs and ensuring their total involvement and commitment to the task in hand. The writing instructors should, therefore, be encouraged to include such practices in their writing classes and utilize these practices to its utmost effect by means of complementary procedures such as error discussion and analysis, grammar exercises, individual and group conferences, and drawing students' attention to specific forms of the target language. 


\section{CONCLUSION}

The research findings clearly revealed that the suggested new practices of CF are to be, though considerately, incorporated in the Saudi EFL context. Issues such as students' varying levels, lack of knowledge and/or practice of particular grammatical forms, students' prior beliefs of $\mathrm{CF}$ and the deep-rooted teacher-centered approach are all to be considered and dealt with for easing the process of implementing such practices in the EFL writing classes.

However, given the tendencies discussed in the present study, further investigation is definitely needed to approximate the differing attitudes and perceptions among students, teachers and stakeholders as to what is a more effective approach of CF. This is because such beliefs of CF is primarily based on teachers and students' prior experiences and shared values manifested persistently in their educational settings. In order to deal with this predicament and approximate the incongruent beliefs, some exploratory and adaptive action must be undertaken considering the setting where $\mathrm{CF}$ is introduced.

To conclude, the present study is not meant for critiquing current EFL teachers' CF practices. Rather, it is a wakeup call to appreciate students' views of CF as they are reflections of their current needs in L2 writing.

\section{REFERENCES}

[1] Ancker, W. (2000). Errors and corrective feedback: Updated theory and classroom practice. English Teaching Forum, 38(4), $20-24$.

[2] Bitchener, J., Young, S., \& Cameron, D. (2005). The effect of different types of corrective feedback on esl student writing. Journal of Second Language Writing, 14(3), 191- 205.

[3] DeKeyser, R. (1993). The effect of error correction on L2 grammar knowledge and oral proficiency. Modern Language Journal, 77, 501-514.

[4] Ellis, R., Basturkmen, H., \& Loewen, S. (2001). Preemptive focus on form in the ESL classroom. TESOL Quarterly, 35, 407432.

[5] Ellis, R. (2005b). Principles of instructed language learning. System, 33 (2), 209-224.

[6] Ellis, R. (2009). Corrective Feedback and Teacher Development. L2 Journal, 1(1), 3-18

[7] Ferris, D. (1999). The case for grammar correction in L2 writing classes: A response to Truscott (1996). Journal of Second Language Writing, 8, 1-11.

[8] Ferris, D., \& Roberts, B. (2001). Error feedback in L2 writing classes: How explicit does it need to be? Journal of Second Language Writing, 10, 161-184.

[9] Ferris, D. (2007). Preparing teachers to respond to students writing. Journal of Second Language Writing, 16(3), 165-193

[10] Ferris, D. R. (2004). The "grammar correction" debate in L2 writing: Where are we, and what do we go from here? Journal of Second Language Writing, 13, 49-62.

[11] Ferris, D. (2011). Treatment of error in second language student writing (second edition). The University of Michigan Press.

[12] Garrett, P., \& Shortall, T. (2002). Learners' evaluations of teacher-fronted and student-centered classroom activities. Language Teaching Research, 6, 25-57.

[13] Green, J. (1993). Student attitudes toward communicative and non-communicative activities: Do enjoyment and effectiveness go together? The Modern Language Journal, 77, 1-10.

[14] Kepner, C. G. (1991). An experiment in the relationship of types of written feedback to the development of second language writing skills. Modern Language Journal, 75, 305-313.

[15] Harmer, J. (2007b). The practice of English language teaching (4th ed.). Harlow: Pearson Education Limited

[16] Hedgcock, J., \& Lefkowitz, N. (1994). Feedback on feedback: Assessing learner receptivity to teacher response in L2 composing. Journal of Second Language Writing, 3, 141-163.

[17] Hyland, F. (2000). ESL writers and feedback: Giving more autonomy to students. Language Teaching Research, 4, 33-54.

[18] Hyland, F. (2003). Focusing on form: Student engagement with teacher feedback. System, 31, 217-230.

[19] Hyland, F., \& Hyland, K. (2001). Sugaring the pill: Praise and criticism in written feedback. Journal of Second Language Writing, 10, 185-212.

[20] Lantolf, J. \& Thorne, S. L. (2007). Sociocultural theory and second language learning. In. B. van Patten \& J. Williams (Eds.), Theories in second language acquisition (pp. 201-224). Mahwah, NJ: Lawrence Erlbaum

[21] Lasagabaster, D., \& Sierra, J. M. (2005). Error correction: Students' versus teachers' perceptions. Language Awareness, 14(23), 112-127

[22] Lee, I. (1997). ESL learners' performance in error correction in writing: Some implications for teaching. System, 25(4), $465-477$.

[23] Lee, I. (2004). Error correction in L2 secondary writing classrooms: the case of Hong Kong. Journal of Second Language Writing, 13 (4), 285-312.

[24] Leki, I. (1991). The preferences of ESL students for error correction in college-level writing classes. Foreign Language Annals, 24, 203-211.

[25] Lightbown, P. M., \& Spada, N. (1999b). Instruction, first language influence, and developmental readiness in second language acquisition. The Modern Language Journal, 83, 1-22.

[26] Littlewood, W. (2011). Communicative language teaching: An expanding concept for a changing world. In E. Hinkel (ed.), Handbook of Research in Second Language Teaching and Learning, Volume II (pp. 541-547). New York: Routledge. Retrieved December 2, 2017, from: https://koreatesol.org/sites/default/files/pdf/Littlewood\%20\%20Teaching\%20English\%20PDF.pdf.

[27] Loewen, S., Li, S., Fei, F., Thompson, A., Nakatsukasa, K., Ahn, S. \& Chen, X. (2009). Second language learners' beliefs about grammar instruction and error correction. The Modern Language Journal, 93, 91-104. Retrieved December 20, 2017, from: https://www.sciencedirect.com/science/article/pii/S1877042811008536. 
[28] Lyster, R., Lightbown, P. M., \& Spada, N. (1999). A response to Truscott's 'What's wrong with oral grammar correction.' The Canadian Modern Language Review, 55, 457-467.

[29] Lyster, R. (2011). Content-based second language teaching. In E. Hinkel (Ed.), Handbook of research in second language teaching and learning, Vol. 2 (pp. 611-630). New York: Routledge.

[30] Mantello, M. (1997). Error correction in the L2 classroom. Canadian Modern Language Review, 54, 127-131.

[31] McCargar, D. (1993). Teacher and student role expectations: Cross-cultural differences and implications. The Modern Language Journal, 77, 192-207.

[32] McDonald, S., \& Salomone,W. (2012). The writer's response: A reading-based approach to writing (5th ed.). Boston, us: Wadsworth

[33] Miley, W. M., \& Gonsalves, S. (2003). What you don't know can hurt you: Students' perceptions of professors' annoying teaching habits. College Student Journal, 37, 447-456.

[34] Morris, F., \& Tarone, E. (2003). Impact of classroom dynamics on the effectiveness of recasts in second language acquisition. Language Learning, 53, 325-368.

[35] Noels, K. (2001). Learning Spanish as a second language: Learners' orientations and perceptions of their teachers' communication style. Language Learning, 51, 107-144.

[36] Noels, K. A., Clément, R., \& Pelletier, L. G. (1999). Perceptions of teachers' communicative style and students' intrinsic and extrinsic motivation. The Modern Language Journal, 83, 23-33.

[37] Norris, J. M. (2009). Task-based teaching and testing. In M.J. Long \& C.J. Doughty (Eds.), The Handbook of Language Teaching (pp. 578-594). Chichester: Wiley Blackwell.

[38] Pawlak, M. (2014). Error Correction in the Foreign Language Classroom: Reconsidering the Issues. Springer Berlin Heidelberg.

[39] Peacock, M. (2001). Match or mismatch? Learning styles and teaching styles in EFL. International Journal of Applied Linguistics, 11, 1-20.

[40] Pica, T. (1994). Questions from the language classroom: Research perspectives. TESOL Quarterly, 28, 49-80.

[41] Pienemann, M. (1998). Language processing and second language development: Processability theory. Philadelphia, PA: John Benjamins.

[42] Porte, G. K. (1997). The etiology of poor second language writing: The influence of perceived teacher preferences on second language revision strategies. Journal of Second Language Writing, 6, 61-78.

[43] Robinson, P. (2011). Second language task complexity, the Cognition Hypothesis, language learning, and performance. In P. Robinson (Ed.), Researching task complexity: Task demands, task-based language learning and performance (pp. 3-38). Amsterdam: John Benjamins.

[44] Savignon, S. J. (2005). Communicative language teaching: Strategies and goals. In E. Hinkel (Ed.), Handbook of research in second language teaching and learning (pp. 635-651). Mahwah, NJ: Lawrence Erlbaum.

[45] Schulz, R. A. (2001). Cultural differences in student and teacher perceptions concerning the role of grammar instruction and corrective feedback. The Modern Language Journal, 85, 244-258.

[46] Semke, H.D. (1984). Effects of the red pen. Foreign Language Annuals, 17, 195-202.

[47] Sheppard, K. (1992). Two feedback types: Do they make a difference? RELC Journal, 23, 103-110.

[48] Straub, R. (1997). Students' reactions to teacher comments: An exploratory study. Research in the Teaching of English, 31(1), 91-119.

[49] Silver, R., \& Lee, S. (2007). What does it take to make a change? Teacher feedback and student revisions. English Teaching:

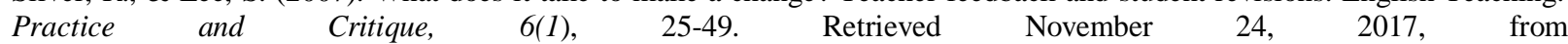
http://education.waikato.ac.nz/research/files/etpc/2007v6n1art.pdf.

[50] Tarone, E., \& Yule, G. (1989). Focus on the language learner. New York: Oxford University Press.

[51] Truscott, J. (1996). Review article: The case against grammar correction in L2 writing classes. Language Learning, 46, $327-$ 369.

[52] Trsucott, J. (1999a). What's wrong with oral grammar correction. Canadian Modern Language Review, 55, 437-456.

[53] Truscott, J. (1999b). The case for "The case against grammar correction in L2 writing classes": A response to Ferris. Journal of Second Language Writing, 8, 111-122.

[54] Truscott, J. (2007).The effect of error correction on learnerse ability to write accurately. Journal of Second Language Writing, $16,255-272$.

[55] Tse, L. (2000). Student perceptions of foreign language study: A qualitative analysis of foreign language autobiographies. The Modern Language Journal, 84, 69-84.

[56] Yang, Y.-F. (2010). Students' reflection on online self-correction and peer review to improve writing. Computers \& Education, 55(3), 1202-1210. https://doi.org/10.1016/j. compedu.2010.05.017.

[57] Yates, R., \& Kenkel, J. (2002). Responding to sentence-level errors in writing. Journal of Second Language Writing, 11, $29-47$.

[58] Zhang, S. (1999). Thoughts on some recent evidence concerning the affective advantage of peer feedback. Journal of Second Language Writing, 8, 321-326.

Sami Ali Al-wossabi is an associate professor of Applied Linguistics at the English department, Jazan University, Saudi Arabia. $\mathrm{He}$ is currently teaching English language courses in Applied Linguistics, Sociolinguistics and Language Acquisition. He has also written articles on different research topics. His main areas of interest include Task-based language teaching (TBLT), communicative language teaching (CLT), computer assisted language learning (CALL), language testing and second language acquisition (SLA). 